\title{
PEMILIHAN KEPALA DAERAH LANGSUNG PERWUJUDAN DARI KEHIDUPAN DEMOKRASI
}

\author{
A.M. YADISAR \\ Fakultas Ilmu Sosial dan Ilmu Politik Universitas Kapuas Sintang \\ Email: yadisara@yahoo.co.id
}

\begin{abstract}
Abstak: Pelaksanaan demokrasi dapat dilakukan dengan dua cara yaitu demokrasi langsung dan perwakilan dan secara hirarkhi negara terdapat demokrasi tingkat nasional dan lokal. Di Indonesia perjalanan demokrasi sudah banyak mengalami kemajuan dan kepercayaan rakyat pada elit politik menjadikan proses rekrutmen mengarah pada demokrasi langsung, termasuk pemilihan kepala daerah. Pemilihan kepala daerah secara langsung merupakan fenomena kenegaraan baru di Indonesia dengan sistem pelaksanaan Pilkada Serentak tahap pertama tahun 2015 dan sisanya akan dilaksanakan pada Pilkada tahun 2017. Hal ini menyusul pemilihan elit eksekutif nasional yang juga dilakukan secara langsung. Pilkada langsung serentak tahap pertama di Kalimantan Barat di ikuti oleh 7 kabupaten/kota, sehingga segala hal yang melandasinya perlu dibahas dengan seksama. Dalam hal ini kita perlu memperhatikan hubungan negara dan rakyat dalam bingkai demokrasi lokal, asas desentralisasi dan proses kebijakan publik dan partisipasi politik rakyat daerah. Kabupaten Sintang yang merupakan salah satu Kabupaten yang ikut dalam pelaksanaan pesta demokrasi pada tahun 2015. Pelaksanaan pemilihan Bupati/Wakil Bupati di Kabupaten sudah berjalan sesuai dengan yang direncanakan mulai dari tahap persiapan sampai pada tahap penyelenggaraan. Pelaksanaan pemungutan suara dilaksanakan pada tanggal 9 Desember 2015 secara serentak di seluruh kecamatan di Kabupaten Sintang, dengan penetapan hasil perolehan suara yang dimenangkan oleh pasangan dr. H. Jarot Winarno,M.Med.PH dan Drs. Askiman, MM. Partisipasi politik masyarakat Kabupaten Sintang dalam pemungutan suara sebesar 75,66\% dari jumlah pemilih.
\end{abstract}

Kata Kunci : Pemilihan, Kepala Deerah, Demokrasi

Sejak bergulirnya reformasi pada pertengahan tahun 1987, kehidupan dalam sistem politik indonesia terus mengalami perubahan dan pergeseran. Banyak yang mengatakan perubahan dan pergeseran sebagai terjadinya dinamisasi hubungan negara-masyarakat (state-civil society). Hal ini ditandai dengan ditandai negara mulai menunjukan sikap politik baru yang lebih responsip dan akomondatif terhadap nilai dan kepentingan masyarakat. Sementara itu ditengah masyarakat sipil muncul kekuatan dalam politik baru yang lebih kritis terhadap kinerja dan kebijakan negara. Agenda ke depan bangsa ini tidak bisa lepas dari upaya penguatan, partisipasi dan kemandirian rakyat lewat proses-proses yang demokratik. Catatan ini penting mengingat karakter dan kamampuan berdemokrasi rakyat masih sangat lemah, sementara secara faktual, rakyat sebenamya hidup di ruang yang sangat terbuka. Persoalan mendasar adalah rakyat bidup di tengah demokratisasi yang mulai terbuka lebar pasca lengsernya Soeharto yang kemudian diiringi oleh kebebasan partisipasi yang luar biasa, akan tetapi belum diiringi oleh kematangan mental dan sikap dalam berdemokrasi. Kebebasan berpolitik, tidak ditopang oleh rasionalitas, daya kritis, dan kemandirian berpikir dan bersikap. Padahal nilai utama yang diusung oleh demokrasi adalah terbukanya ruang-ruang politik rasional dalam diri setiap rakyat. Kebebasan yang tidak didasari oleh rasionalitas politik akhir-akhir ini sangat nampak dalam upaya penguatan kekuasaan pada aras politik lokal. Peluang konflik politik dalam perebutan kekuasaan akan meningkat seiring ditetapkannya mekanisme Pemilihan Kepala Daerah (Pilkada) secara langsung serentak pertama tahun 2015. Di tengah belum menguatnya kesadaran poitik di level grass root, maka momentum Pilkada menjadi pertarungan politik yang selalu membuka ruang potensi konflik, manipulasi, money politics, dan intimidasi.

Dalam konteks penguatan demokratisasi, pilkada langsung sebenarnya berpeluang untuk melakukan pematangan dan penyadaran berdemokrasi. Rakyat yang memiliki kesadaran berdemokrasi adalah langkah awal dalam menuju lajur demokrasi yang benar. Sebagaimana disampaikan Murray Print (1999), pembentukan 
warga negara yang memiliki keadaban demokratis dan demokrasi keadaban paling mungkin dilakukan secara efektif hanya melalui pendidikan kewarganegaraan (civic education). Aktualisasi dan civic education sebenarnya terletak kepada tingkat partipasi poitik rakyat di setiap momentum politik seperti pemilu. Partisipasi politik yang lemah berakibat pada sebuah realitas politik yang kini menggejala di permukam dan terkait dengan, era otonomi daerah yaitu terjadinya kesenjangan politik antara masyarakat sipil dengan lembaga kekuasaan lokal, di mana aktor pelaksana kekuasaan lokal (baik unsur birokrasi maupun legislatif) sering melakukan langkah pengambilan dan pelaksanaan kebijakan politik yang tidak selaras dengan aspirasi kolektif masyarakat sipil. Lembaga kekuasaan politik lokal yang sebagian besar didominasi kalangan partai politik peraih suara Pemilu yang lalu seringkali tidak mampu menjalankan fungsi keterwakilan politik dan kurang optimal dalam peran sebagai pelayan aspirasi publik. Partisipasi politik rakyat adalah keterlibatan rakyat secara perseorangan (privat citizen) untuk mengerti, menyadari, mengkaji, memelobi dan memprotes suatu kebijakan yang ditelurkan oleh pemerntah dengan tujuan mempengaruhi kebijakan agar aspirasi terhadap kepentingan mereka. Dari ilustrasi di atas, partisipasi rakyat bisa dipahami sebagai keterlibatan rakyat dalam pengertian politik secara sempithubungan Negara dan masyarakat (dalam bingkai governance)-dan juga politik secara luas-semua bentuk keterlibatan masyarakat dalam proses berhimpun untuk mempengaruhi ataupun melakukan perubahan terbadap keputusan yang diambil partisipasi politik rakyat sebetulnya adalah tema sentral dan proses demokratisasi Dalam kerangka inilah masyarakat bisa berperan sebagai subyek dalam menentukan arah masa depan society-nya.

Di Indonesia perdebatan tentang partisipasi politik hanya terbatas pada angka tingkat partisipasi masyarakat dalam setiap pemilihan umum. Sebelum reformasi bergulir, angka itu selalu berada pada kisaran 90 persen, maka dengan mudah orang akan menyebut bahwa partisipasa politik masyarakat tinggi. Tapi sebetulnya bukan itu, atau tepatnya bukan satu-satunya ukuran tentang tingginya tingkat partisipasi masyarakat dalam pemilihan umum. Yang Iebih penting adalah adanya jaminan dan mekanisme yang baku, dan comfortable bagi semua rakyat untuk dapat menyalurkan pikiran-pikirannya kedalam sebuah institusi formal. Satu peran rakyat yang amat penting adalah melakukan social control terhadap pemerintah, maupun institusi-insitusi lain seperta DPR ataupun peradilan. Secara kasat mata mungkin bisa kita mengatakan bahwa partisipasi politik masyarakat akhir-akhir ini meningkat. Intensitas demo yang makin marak, interaktif TV dan radio yang makin mendominasi program- program massa, serta meningkatnya keterlibatan publik dalam perdebatan tentang satu wacana tertentu. Hubungan antara pemerintahan (state) dengan warga negara/rakyat (society) selalu berada dalam bingkai interaksi politik diantara keduanya dalam wujud organisasi negara. Hubungan state and society ini dapat tergambarkan dalamicon yang diberi label demokrasi. Sejak lama, sebagai gambaran besar, demokrasi menjadi cara terbaik dalam perkembangan organisasi negara modern. Demokrasi yang dimaksud merupakan instrumen universal, namun juga memiliki karakteristik ideografis dalam hal-hal tertentu. Misalnya kita akan menemukan adanya demokrasi liberalis, demokrasi sosialis dan bahkan demokrasi Pancasila. Sementara dalam hirarkhi suatu negara jangkauan pengaruh, kita bisa merujuk pada dua jenis atau kelompok demokrasi, yaitu demokrasi dalam lingkup negara dan demokrasi lokal.

Tulisan ini bermaksud mendeskripsikan demokrasi dalam tataran lokal pada ranah ideografis Indonesia dengan memfokuskan diri pada fenomena pemilihan kepala daerah secara langsung di Kabupaten Sintang Provinsi Kalimantan Barat.

Desentralisasi merupakan salah satu asas dalam penyelenggaraan pemerintahan yang bertujuan untuk sharing power dalam penyelenggaraan pemerintahan yang dekat dengan rakyatnya. Sementara itu, Cornelis Lay (2003) menyatakan bahwa dengan desentralisasi pengaturan politik dan pemerintahan yang stabil dapat dilakukan. Dengan desentralisasi dapat diakomodasi sharing of power, sharing of revenue, dan penguatan lokalitas, selain pengakuan dan penghormatan terhadap identitas daerah. Berkaitan dengan sharing of power maka pemberian desentralisasi secara devolusi menjadi penting. Apalagi dalam era reformasi ini yang akan memunculkan pemilu lokal bagi elit ekesekutif secara langsung tentunya akan terjadi penguatan dalam sistem pemerintahan daerah. Desentralisasi merupakan bentuk hubungan antara pemerintah pusat dan pemerintahan daerah yang pada umumnya memiliki dua bentuk yaitu: Devolusi dan dekonsentrasi. Dalam ideografis Indonesia kita pernah mengenal asas tugas pembantuan atau medebewind sebagai bagian dari desentralisasi. Berdasarkan ranah politik pemerimtahan maka desentralisasi yang berkaitan dengan otonomi penyelengaraan pemerintahan di daerah adalah devolusi. Sementara dekonsentrasi masih merupakan kepanjangan tangan kebijakan pusat di daerah.

Asas desentralisasi ini memberikan peluang bagi daerah untuk dapat mengurus rumah tangga pemerintahan sendiri walaupun tetap dalam bingkai sistem negara kesatuan. Dengan asas ini pula secara garis besar rekrutmen, responsibilitas dan 
akuntabilitas politik dapat dilaksanakan dan bersifat final di pemerintahan daerah. Berdasarkan asas desentralisasi hubungan rakyat dan pemerintahan daerah berada dalam koridor demokrasi daerah. Pelibatan pemerintahan daerah dalam mengurus kewenangannya merupakan keleleuasaan yang bertujuan untuk pengembangkan demokrasi daerah dan pembangunan daerah yang pada gilirannya mengarah pada kesejahteraan rakyat di wilayah kerja daerahnya. Dalam perkembangannya asas desentralisasi yang berbentuk devolusi telah mengalami perubahan yang mendasar. Salah satu contoh yang sekarang menjadi isu nasional adalah tentang pemilihan kepala daerah baik di pemda propinsi maupun pemda kabupaten dan kota. Berdasarkan Undang-undang no 5 tahun 1974 rekrutmen eksekutif daerah berada di legilslatif daerah dengan masih ada intervensi dari pemerintah pusat. Berdasarkan undang-undang no 22 tahun 1999, kepala daerah dipilih oleh legislatif daerah secara mandiri. Dan pada perkembangan berdasarkan undang-undang no 32 tahun 2004 yang telah direvisi dengan undang-undang no 9 tahun 2015 tentang pemerintah daerah, pemilihan eksekutif daerah didasarkan pada demokrasi lokal partisipatif, dimana rakyat daerah yang bersangkutan melakukan pemilihan secara langsung. Sementara itu pelaksana atau penyelenggara pemilu yang berdasarkan dua undang-undang pemerintahan daerah terdahulu berada dalam legislatif daerah, untuk pemilu eksekutif daerah yang akan dilaksanakan serentak tahap pertama pada tahun 2015 ini berada di Komisi Pemilihan Umum Daerah yang bertangung jawab pada legislatif daerah. Dalam hal ini terdapat lompatan besar dalam rekrutmen eksekutif daerah.

Semangat desentralisasi telah bergerak dari seputar lingkaran pemerintah pusat dan legislatif daerah ke arah rakyat daerah yang berdaulat. Tentunya lompatan ini harus diimbangi dengan format pelaksanaan yang jelas baik secara politik, hukum maupun adminstrasi negara. Kenapa demikian? Hal ini berkaitan dengan tingkat kerawanan dan tantangan yang begitu besar dalam melakukan pemilu eksekutif lokal secara langsung. Konflik yang akan muncul juga akan semakin kompleks dari pemilu presiden dan wakil presiden. Sehingga payung hukum, politik dan administrasi negara menjadi penting. Ada kegelisahan dalam memaknai desentralisasi secara tersendiri apabila pada tahun 2015 ini terjadi hal yang merugikan asas ini. Terdapat sekitar 7 pasangan eksekutif daraih yang akan dipilih langsung tahap pertama tahun 2015 merupakan Pemilihan Kepala Daerah Secara Langsung di Pemerintahan Daerah di Kalimantan Barat, tentunya perlu penanganan yang baik, sehingga tidak terjadi shifting dari major descentralisation ke arah major deconsentration atau bahkan memunculkan resentralisasi sebagai sisi ekstrim dari desentralisasi.

Memang benar menurut kajian kebijakan publik semua produk kebijakan yang sudah melalui tahapan-tahapan formal kebijakan yang berlaku, setelah menadapat penetapan dan dimuat dalam lembataran negara dan tambahan lembaran negara menjadi sah secara hukum positif untuk dilaksanakan. Namun demikian, dalam kerangka politik yang secara mendasar mengarah pada esensi demokrasi, hal ini menimbulkan berbagai pertanyaan yang krusial. Seperti contohnya muncul pertanyaan tentang kemandirian penyelenggara pemilu, dan yang lainnya. Disamping itu berkaitan dengan sistem pemerintahan dalam format desentralisasi dan sentralisasi terdapat pertanyaan tentang hasil kebijakan publik yang kontradiktif terutama dalam pertanggungjawaban pelaksana pemilu dalam hal ini KPUD dengan legislatif daerah. Terdapat kehawatiran lain berkaitan dengan sinyalemen intervensi pemerintah pusat melalui struktur lembaganya dalam prosedur pelaksanaan pilkada langsung ini. Bila dilihat dari tahapan pembuatan kebijakan publik di Indonesia, khususnya dalam pembuatan undang-udang no 9 tahun 2015, kita bisa melihat adanya ketergesaan dalam pembahasannya sehingga hasilnya banyak dipertanyakan. Salah satu pertanyaan mendasar adalah pembuatan rancangan undang-undang itu tertutup dan kurang melibtakan komponen masyarakat terkait. Dalamkajian kebijakan publik tahapan pembuatan rancangan baik oleh eksekutif maupun legislatif seharusnya melibatkan stakholder dalam kebijkan publik tersebut, namun kenyataannya hal ini jarang sekali dilakukan sehingga kelompok-kelompok masyarakat yang berkepentingan dengan kebijkan tersebut sangat sulit untuk mendapatkan akses informasi perkembangannya. Berkaitan dengan RUU perubahan UU No. 8 tahun 2015 tentang Pemilihan Gubernur, Bupati dan Wali Kota dan UU No. 9 tahun 2015 tentang Pemerintah Daerah, dengan sangat terbatas rancangan yang berasal dari eksekutif, legislatif dan dari kalangan LSM bisa diakses. Kemudian ketika memasuki tahapan formal juga terjadi hal yang serupa. Sehingga sinyalemen yang menganggap pembahasan kebijakan ini tidak rasional dan cenderung instan dapat dibenarkan dan memenuhi hasrat kepentingan politik. Selain itu juga ketika pembahasan itu dilakukan Dewan Perwakilan Daerah sudah terbentuk sebagai hasil pemilu, tetapi mereka tidak dilibatkan secara intensif di dalamnya padahal kebijkan publik tersebut menyangkut salah satu kewenanggannya. Asosiasi pemerintah daerah maupuin eksekuit daerah juga tidak secara optimal diberikan akses, apalagi kelompok-kelompok lainnya dalam masyarakat yang sebenarnya perlu mengikuti tahapan-tahapan dalam pembahasan rancangan. 
Memang benar secara formal tahapan-tahapan kebijakan publik sudah dilakukan secara prosedural, namun demikian dengan waktu yang terbatas dan kurang melibatkan lembaga negara baru tersebut merupakan kelemahan tersendiri.

\section{METODE PENELITIAN}

Sesuai dengan permasalahan dalam penelitian ini, yaitu kajian terhadap Pemilihan Kepala Daerah Langsung Di Kabupaten Sintang Provinsi Kalimantan Barat, maka penelitian ini adalah penelitian pustaka (library research), sehingga data-data sepenuhnya diambil dari bukubuku yang mengkaji demokrasi lokal, khususnya yang memfokuskan pada pemilihan langsung kepala daerah di Kalimantan Barat lebih khusus di Kabupaten Sintang. Untuk mendukung data primer penulis menggunakan data yang dikeluarkan secara resmi oleh Komisi Pemilihan Umum Kabupaten Sintang dan buku-buku yang mengupas dan memberi komentar-komentar tentang pemikiran demokrasi local sebagai data sekunder. Data sekunder juga diambil dari buku-buku, makalah-makalah, majalah, jurnal dan sebagainya yang berkaitan dengan demokrasi dan pemilukada. Dalam menganalisis data yang diperoleh, peneliti menggunakan metode kajian isi (content analisys) yaitu metode yang digunakan untuk mengungkapkan isi sebuah data-data dan buku atau pemikiran seseorang yang menggambarkan situasi penulis dan masyarakatnya pada waktu buku itu ditulis atau pemikiran itu ditelorkan (Nawawi, 2001 :68), dan juga telaah historis.Untuk menganalis lebih mengenai demokrasi dalam penelitian ini, digunakan metode komparasi, yaitu dengan membandingkan perjalanan pemilihan kepala dearah di Kalimantan Barat terutama di Kabupaten Sintang. Kesimpulan akhir yang akan diperoleh dalam penelitian ini adalah pemikiran deskriptif tentang demokrasi .

\section{HASIL DAN PEMBAHASAN}

\section{Pemilihan Kepala Daerah Langsung Perwujudan Dari Kehidupan Demokrasi}

Demokrasi sebagai aspek penting berkaitan dengan pemerintahan dengan hirarkhi kekuasaan yang terdapat dalam suatu sistem politik negara. Artinya, akan terdapat sistem politik nasional yang didalamnya terdapat sub sistem politik daerah dalam bingkai sistem negara yang dianutnya. Pemilahan demokrasi lokal ini bukan berarti terdapat determinasi wilayah pemberlakuan demokrasi atau bahkan terdapat perbedaan demokrasi dari induknya. Dalam tulisan ini demokrasi lokal ditujukan sebagai bagian utuh dari demokrasi di Indonesia dalam pelaksanaan rekrutmen elit politik di pemerintahan daerah. Demokrasi lokal merupakan bagian dari subsistem politik suatu negara yang derajat pengaruhnya berada dalam koridor pemerintahan daerah. Di Indonesia Demokrasi lokal merupakan subsistem dari demokrasi yang memberikan peluang bagi pemerintahan daerah dalam mengembangkan kehidupan hubungan pemerintahan daerah dengan rakyat di lingkungannya. Semenjak era reformasi, demokrasi yang diusung mengarah pada demokrasi partisipatif atau langsung, salah satunya karena banyak pejabat politik yang tidak melakukan tanggung jawabnya dengan baik, sehingga legitimasi mereka lemah. Di sisi lain memunculkan ketidak percayaan rakyat pada penguasa mendorong rekrutmen pejabat politik ke arah demorasi langsung. Sehingga tidak mengherankan bila rekrutmen hampir semua jabatan politik dilaksanakan dalam format demokrasi yang bergerak pada hubungan state and society secara langsung. Mulai dari pemilihan anggota DPR, DPD, dan DPRD. Kemudian dilanjutkan dengan pemilihan umum presiden dan wakil presiden. Pada fase demokrasi langsung ini merupakan era baru reformasi politik di Indonesia yang pertama kali digelar sejak kemerdekaan Indonesia. Rekrutmen politik skala nasional ini merupakan perkembangan demokrasi yang mendapat pengakuan dunia karena keberhasilannya.

Demokrasi lokal dalam pemilihan kepala daerah, menjadi momentum yang masih memberikan pertanyaan besar dalam pelaksanaannya. Pertanyaan ini berkaitan dengan demokrasi partisipatoris yang akan dilakukan. Betapa tidak, pemberian kedaulatan rakyat daerah pada elitnya masih diwarnai ketidakjelasan, baik dari prosdur kerja penyelenggara maupun peserta dan posisi pemilihnya. Dari sisi kedaulatan rakyat daerah, demokrasi lokal dibangun untuk memberikan porsi yang seharusnya diperoleh rakyat lokal dalam pemberian legitimasi pada elit eksekutifnya. Selama ini rakyat daerah memberikan kedaulatan hanya pada legislatif daerah saja-melalui pemilu legislatif. Maka merujuk pada konsep trias politica-nya Montesquieu pemisahan kekuasaan atas tiga lembaga negara untuk konteks pemerintahan daerah terletak pada lembaga eksekutif dan legislatif daerah, sedangkan dalam kerangka yudikatif menginduk pada kelembagan pusat. Hal ini terkait dengan pola hubungan pemerintahan pusat daerah dalam asas desentralisasi. Kedaulatan rakyat dalam kerangka sistem pemerintahan dapat dibagi kedalam hirarkhi demokrasi nasional dan lokal dari tata cara rekrutmen politiknya.

Ketidakpercayaan rakyat dan era reformasi mendorong adanya pilkada langsung. Hal ini tidak langsung berkatan dengan baik atau tidaknya demokrasi, karena di negara lain uga terdapat variasi pelaksanaan demokrasi baik yang langsung, 
perwakilan bahkan dengan appointment. Derajat kepentingannya adalah terpilihnya pejabata politik yang akuntabel sesuai dengan needs for achievment rakyatnya. Berdasarkan pembahasan, pemilu eksekutif daerah ini berada dalam koridor demokrasi lokal dalam lingkup asas pemerintahandesentralisasi dan didasaraan pada rel kebijakan publik UU No. 8 tahun 2015 tentang Pemilihan Gubernur, Bupati dam Walikota. Pemilihan Kepala daerah langsung merupakan fenomena tersendiri dalam sistem pemerintahan daerah di Indonesia. Sepanjang sejarah pemerintahan, baru sekarang ini akan dilaksanakan pilkada langsung serentak di Seluruh Indonesia. Melihat begitu banyaknya pemerintah daerah yang akan melaksanakan pilkada tersebut, maka akan menjadi sangat penting bagi semua komponen yang terlibat dalam pelaksanaannya untuk memiliki persepsi yang sama, sehingga tahun 2015 ini bisa dijadikan tonggak demokrasi lokal di Indonesia. Akan sangat riskan ketika dalam pelaksanaan di pemerintahan daerah itu terjadi konflik atau permasalahan yang akan merusak dan berakibat fatal pada sistem pemerintahan di Indonesia. Provinsi Kalimantan Barat terdapat 7 kabupaten yang melaksanakan Pemilihan Kepala Derah secara Langsung yaitu: Kabupaten Ketapang, Kabupaten Bengkayang, Kabupaten Sambas, Kabupaten Sekadau, Kabupaten Sintang, Kabupaten Melawi dan Kabupaten Kapuas Hulu. Berdasarkan UU No. 8 tahun 2015 tentang Pemilihan Gubernur, Bupati dam Walikota, kita dapat membahas adanya perkembangan demokrasi yang semakin dekat dengan konstituennya yaitu masyarakatnya. Secara umum ini merupakan kemajuan yang sangat berarti bagi hubungan pemerintahan daerah dengan rakyatnya dalam hal penggunaan hak politiknya. Namun demikian secara lebih mendalam masih banyak hal yang perlu mendapat perhatian serius. Salah satu kekhawatiran itu munculnya usaha judicial review dari komponen masyarakat pada Mahkamah Konstitusi terhadap hal yang akan mengurangi kadar demokrasi yang dimaksudkan. Sebagai suatu sistem pemilihan partisipatif yang akan dilaksanakan di Indonesia ter utama di Provinsi Kalimantan Barat ini, tentunya perlu diperhatikan keunggulan dan kelemahan dari produk kebijakan publik tentang pemilu dalam rekrutmen elit eksekutif lokal ini. Melalui format demokrasi yang sampai saat ini dianggap paling baik dalam memetakan hubungan negara dan rakyatnya baik dalam tataran politik nasional maupun lokal, dapat kita gambarkan keunggulan dan kelemahan pilkada langsung ini.

Keunggulan pilkada langsung ini bisa dilihat dari adanya legitimasi elit eksekutif lokal terpilih berkaitan dengan dukungan rakyat daerah kepadanya yang sebanding dengan pemilu legislatif daerah yang menjadi satu paket dengan pemilihan
DPR dan DPD. Jadi berdasaarkan aspek legitimasi, pilkada langsung merupkan salah satu keunggulan yang siginifikan. Berikutnya adalah berperannya rakyat daerah dalam menentukan langsung pilihannya, tidak mewakilkan pada DPRD seperti pada periode pemilihan kepala daerah berdasarkan UU No. 22 tahun 1999. Secara umum pemberian hak politik dalam menentukan elit eksekutif lokal ini merupakan keunggulan dari UU pemerintahan daerah yang baru. Membatasi terjadinya politik uang dikalangan elit pemerintahan daerah, yang pada waktu pilkada lalu bermuara pada penyelenggranya, yaitu DPRD melalui kepanjangan tangan fraksi. Jadi dimungkinkan melemahnya politik uang tentunya apabila dipenuhi syarat dalam pencalonan dan pemilihannya. Selain itu juga memberikan kesan lebih obyektif. Rakyat pemilih juga sudah terbiasa dalam rekrutmen langsung kepala desa. Bahkan baru-baru ini di akhir tahun 2014, kita sudah berhasil dalam melakukan rekrutmen elit eksekutif nasional dalam pemilu presiden dan wakil presiden secara langsung.

Sedangkan bila dibahas berdasarkan kemungkinan kelemahan yang akan terjadi, kita bisa mendeteksi adanya pengalihan money politics dari lembaga DPRD ke partai politik yang memiliki hak untuk mengajukan calon. Tidak menutup kemungkinan pula terjadinya money politics ini meluas pada komponen-komponen masyarakat lainnya. Kastorius Sinaga (2003) menyatakan bahwa dalam kerangka sistem negara unitarian tidak dimungkinkan adanya negara dalam negara. Artinya bingkai sistem pemerintahan daerah merupakan bagian dari atau subsistem dari sistem pemerintahan nasional. Secara hirarkhi, pemerintah pusat merupakan atasan bagi pemerintahan daerah. Namun demikian akan terjadi tendensi kelemahan dalam peluang intervensi pemerintah pusat dalam pilkada langsung ini. Banyak kalangan akademisi dan LSM yang menengarai warna resentralisasi dalam pesta demokrasi lokal ini. LSM Cetro menyatakan bahwa akan terjadi intevensi pemerintah pusat bila Peraturan Pemerintah sebagai amanat dari undangundang mengatur terlalu banyak KPUD sebagai penyelenggara pilkada langsung di satui sisi dan meniadakan sifat independen, mandiri dan nasional.

Aktor berikutnya adalah elit-elit partai politik dalam hirakhi lokal. Mereka ini merupakan partai politik yang memiliki kursi di DPRD. Parpol ini akan melakukan penjaringan calon pasangan kepala daerah, yang tentu saja memiliki kewenangan penuh untuk meloloskan atau tidak calon pasangan tadi. Hal ini dimungkinkan karena satu-satunya pintu bagi pencalonan pasangan kepala daerah hanya melalui mereka. Aktor lain dalam pilkada yang sebenarnya merupakan pemegang kedaulatan poitik dalam aras lokal adalah rakyat 
pemilih. Hak Politik mereka akan sangat menentukan kemenanganan pasangan calon kepala dan wakil kepala daerah. Jumlah pemilih yang menggunakan haknya secara sah akan mengantarkan pasanagan calon menjadi elit eksekutif daerah. Lembaga eksekutif daerah juga berperan sebagai fasilitator dalam tahapan persiapan dan pelaksanaan pilkada langsung itu.

Aktor yang berada dalam bayang-bayang secara implisit memunculkan pengaruhnya adalah kelompok pemodal yang mempunyai kepentingan yang bersandar pada sosok pasangan calon yang akan terpilih. Apabila berdasarkan kasus-kasus pemilihan terdahulu yang berada dalam lingkup DPRD, mereka berada di balik dukungan melalui organ DPRD itu, namun untuk pilkada langsung ini, tentunya akan melalukan cara yang berbeda. Tujuan akhirnya menjadikan jagoannya terpilih dan pada gilirannya akan memberikan peluang bagi kepentingannya. Sinyalemen ini mulia berkembang karena dalam pilkada dengan sistem yang berbeda sudah sering terjadi, dimana suara DPRD sebagai wakil rakayat tersisihkan menjadi sekedar wakil kepentingan kaum pemodal ini. Tapi mudahmudahan dalam pilkada langsung ini, pengaruh mereka tidak ada atau dapat dipersempit ruang geraknya. Perlu kesadaran tinggi sebagai warga negara yang baik, legislator yang baik dan elit partai politik yang baik pula untuk memeranginya.

Dalam pentahapan penyelenggraan pilkada langsung ini, dalam UU No. 8 tahun 2015 tentang Pemilihan Gubernur, Bupati dam Walikota merunut pada pentahapan pemilihan legislatiuf dan secara khusus pada pemilu presiden. Tahapan dimulai melalui berakhirnya masa jabatan kepala daerah, kemudian ke pendaftaran pemilih, pendaftaran calon peserta pilkada, kampanye dan pemungutan dan pengitungan suara, penetapan calon terpilih dan pelantikan calon terpilih sebagai pasangan kepala daerah dan wakil kepala daerah. Di dalamnya termasuk sosialisasi tahapan-tahapan tadi, yang secara garis besar terbagi ke dalam dua tahapan yaitu tahapan persiapand ana tahapan pelaksanaan. Derajat kepentingan tahapan ini tentunya berbedabeda diantara aktor-aktor yang berkaitan dengan pilkada langsung ini, bagi pemilih sebagai warga negara yang baik maka tahap pendaftaran pemilih, partsispasi dalam kampanye, dan tahapan pemungutan suara menjadi tiga tahapan penting disamping peka terhadap sosialisasi yang dilakukan oleh fihak penyelenggara. Bagi KPUD tentunya semua tahapan menjadi penting berkaitan dengan tugas dan kewajiban dalam mensuksekan tugas ke tiganya dalam pilkada langsung ini. Bagi DPRD tentunya juga sangat memperhatikan fungsi sebagai penanggungjawab penyelenggaraan pilkada langsung ini terutama dalam penetapan anggaran, diferensiasi fungsi lembaga dan sebagai kepanjangan partai politik, juga dalam pemilihan panitia pengawas pemilu. Apabila semua aktor yang terlibat berperan sebagaimana fungsinya masingmasing dalam koridor kebijakan publik yang berlaku, maka diharapkan pilkada langsung yang akan dislenggarakan di setengah pemda propinsi dan di pemda kabupaten dan kota di seluruh Indonesia, akan menjadi tonggak sejarah perkembangan demokrasi lakal serentak

Kabupaten Sintang merupakan salah satu kabupaten yang ikut melaksanakan pemilihan Bupati/Wakil Bupati pada tahun 2015. Hasil penelitian menunjukan bahwa .serangkaian tahapan pemilihan Bupati/Wakil Bupati mulai dari tahapan persiapan seperti perencanaan program dan anggaran; penyusunan peraturan penyelenggaraan pemilihan; perencanaan penyelenggaraan meliputi penetapan tata cara dan dan jadwal pelaksanaan pemilihan; pembentukan PPK, PPS dan KPPS; pembentukan Panwas Kabupaten, Panwas Kecamatan, PPL, dan Pengawas TPS; pemberitahuan dan pendaftaran pemantau pemilihan; dan penyerahan daftar penduduk potensial pemilih. Serta tahapan penyelenggaraan yang meliputi pendaftaran bakal calon; uji public; pengumuman pendaftaran calon; pendaftaran calon; penelitian persaratan calon; penetapan calon; pelaksanaan kompanye; pelaksanaan pemungutan suara; perhitungan suara dan rekapitulasi perhitungan suara; dan penetapan calon terpilih. Serangkaian tahapan persiapan dan penyenggaraan berjalan dengan baik sesuai dengan yang direncanakan. Pemilihan Bupati/Wakil Bupati pada tahun 2015 di ikuti 3 pasangan calon yaitu calon nomor urut 1: Agrianus, S.Sos.M.Si dan Muhammad Chomain Wahab, SH; calon nomor urut 2: Drs. Ignasius Juan, MM dan Drs.H. Senen Maryono, M.Si; calon nomur urut 3: dr.H. Jarot Winarno, M.Med.PH dan Drs. Askiman, MM. Pasangan calon Pemilihan Bupati/Wakil Bupati pada tahun 2015 semuanya berasal dari usulan gabungan partai politik dan tidak ada pasangan melalui jalur perorangan (independen). Pelaksanaan pemungutan suara dilaksanakan serempak di 14 kecamatan di Kabupaten Sintang pada tanggal 9 Desember 2015.

\section{Partisipasi Politik}

Di tengah negara-negara demokrasi, sangat mungkin Indonesia termasuk negara yang paling sering menggelar pesta demokrasi. Mulai dari pemilihan umum kepala Desa (pemilukades), pemilihan umum kepala daerah (pemilikada) kabupaten kota/provinsi, Pemilu Presiden (pilpres), hingga Pemilu legislatif. Jika dikaitkan dengan luasnya wilayah negeri ini, yang juga diikuti dengan banyaknya struktur kepemerintahan, pesta demokrasi itu seakan menjadi acara ritual demokrasi sepanjang tahun bahkan sepanjang bulan. Tentunya 
cukup besar biaya yang mesh dikeluarkan untuk melangsungkan hajatan ini. Juga cukup banyak pengalaman demokrasi yang bisa diperoleh bangsa ini dari pesta rakyat ini. Pesta demokrasi, apapun bentuknya, tentu berangkat dari spektrum demokrasi. Pesta ini selau diawali dengan niatan hendak memenuhi tuntutan demokrasi. Pesta ini dijalankan berdasarkan proses-proses dan nilai-nilai demokrasi. Pesta ini juga diharapkan bisa melahirkan sebuah hasil yang sejalan dan sesuai dengan kriteria demokrasi. Dengan demikian pemilukades, pemilukada, pilpres dan pemilu legislatif adalah pesta-pesta yang dijalankan untuk dan atas demokrasi. Semuanya hanya merupakan sarana hanya menuju demokrasi dan bukanlah sekedar bertujuan untuk memilih dan melegimitasi pemimpin dan wakil-wakilnya. Lebih dari itu, untuk mengupayakan bagaimana agar nilai-nilai demokrasi dapat tumbuh subur dan berkontribusi positif bagi peningkatan kesejahteraan rakyat.

Tidak dipungkiri, setiap pesta demokrasi tentu mengimplikasikan adanya perbedaan pendapat dan sikap di tengah peserta atau siapapun yang terlibat dalam pesta demokrasi. Baik antar pemilih, antar yang dipilih, maupun antara pemilih dan yang dipilih. Perbedaan itu tentunya merupakan hal yang sahsah saja, lumrah, fitrah, bahkan dibenarkan dalam teori demokrasi. Sebab, demokrasi sejatinya memberikan ruang yang luas bagi setiap individu dalam mengekspresikan pendapat dan sikap atas keputusan bersama yang akan diambil.

Ketika telah lahir kepuasan bersama yang didukung suara mayoritas dan diasumsikan sebagai keputusan terbaik, maka menjadi kewajiban bagi setiap individu yang berbeda pendapat dan sikap itu untuk menghargai dan mendukung keputusan tersebut. Pilkada langsung yang akan diselenggrakan mulai tahun 2015 ini, tidak akan terlepas dari pentingnya partisipasi politik rakyat. Kalaupun tidak ada batasan yang jelas bahwa jumlah pemilih yang menggunakan haknya secara sah sebagai indikator keberhasilan pemilu tersebut, namun kita bisa melihat derajat partispasi politik sebagai respon atas pentingnya rekrutmen politik elit daerah. Banyak batasan yang diberikan oleh ahli-ahli politik dalam literatur-literaturnya. Salah satu definisi Partisipasi politik yang berkaitan dengan pilkada langsung ini dapat dilihat dari pendapatnya Miriam Budiardjo (1994) yang menayatakan bahwa "Kegiatan individu atau kelompok secara aktif dalam kehidupan politik, memilih pimpinan negara dan terlibat dalam mempengaruhi kebijakan publik" sebagai batasan dari partisipasi politik. Hal senada juga diungkapakan oleh Herbert McClosky yang dikutip oleh Budiardjo (1994) yang berkaitan dengan sifat sukarela dan proses pemilihan penguasa. Keterlibatan secara sukarela dalam pilkada merupakan indikator positif atau negatifnya rakyat daerah sebagai warga yang mempunyai hak politik sebagai voter. Tentu saja rakyat sebagai waraga negara agar dapat berperan aktif dalam partisipasi politik perlu terpaan pendidikan politik dari berbagai agennya. Tanpa terpaan itu maka sukar untuk mendapatkan kadar partispasi politik yang baik dalam kerangka demokrasi.

Bentuk partispasi politik rakyat daerah dalam pilkada langsung ini dapat dilihat dari berbagai bentuknya, mulai dari sebagai orang atau kelompok yang apolitis, pengamat, maupun partisipan Seperti pada dua pemilu yang lalu maka akan ada prosentasi rakyat yang apolitis dalam arti mereka yang termasuk tak acuh dalam kegitand an proses politik. Sementara bentuk pengamat merupakan porsi yang paling banyak, yaitu mereka yang melakukan pengaruh dalam proses politik sebatas sebagai anggota organsisasi, hadir dalam kampanye, dan voter. Sementara dalam bentuk partisipan, diantaranya rakyat terlibat sebagai aktivis partai, dan kelompok kepentingan. Sebagai aktivis, pertisipasi politik rakyat sudah mengarah pada derajat menduduki jabatan-jabatan organisasi/ politik. Sifat sukarela dan terlibat dalam rekrutmen politik serta mempengaruhi kebijakan publik merupakan warna proses politik yang dapat digambarkan dalam pemilu legisltaif adan pemilu presiden secara langsung pada tahun 2014 yang lalu. Hal yang sama juga dapat diprediksikan pada pilkda langsung tahun 2015 nanti. Kenapa ada statemen demikian? hal ini tidak terlepas dari pengalaman praktis rakyat dalam pemilu langsung tadi. Dengan tata cara dan tahapan yang relatif sama dengan pemilu presiden diperkirakan partisipasi politiknya juga tidak jauh berbeda. Namun demikian untuk menghindari antiklimaks dari partisipasi politik rtakyat daerah maka perlu media sosialisasi politik termasuk di dalamnya pendidikan politik yang memadai sehingga rakyat daerah akan merespon dalam bentuk pertisipasi politik yang memadai baik dari sudut pandang kualitas mapun kuantitasnya.

Partisipasi masyarakat Kabupaten Sintang dalam pilkada langsung tahun 2015 dapat terlihat dari daftar pemilih yang terdaftar dalam daftar pemilih tetap sebesar 299.100 dan yang menggunakan hak pilihnya sebesar 225.349 $(75,34 \%)$, sehingga $73.751(24,66 \%)$ pemilih yang tidak menggunakan hak pilihnya. Apabila dilihat dari data pemilih, jumlah pemilih adalah sebesar 303.591 dan yang menggunakan hak pilih sebesar 229.685 (75,66\%), sehingga 73,906 (24,34\%) pemilih yang tidak menggunakan hak pilihnya. Peran partai politik sebagai penyandang fungsi sosialisasi, pendidikan, partisipasi dan rekrutmen politik merupakan media yang sangat efektif dalam memicu partisipasi politik rakyat daerah. Disamping itu, peran KPUD dalam sosialisasi tahapan pilkada 
langsung juga berpengaruh pada tingkat partisipasi politik dalamap pilkada langsung ini. Terpaan pendidikan politik dari berbagai agenda dalam pilkada yang dilakukan dengan baik akan berdampak pada kontribusi partisipasi politik yang baik pula. Peran partai politik yang melakukan penjarinag calon pasangan dengan obyektif dan sesuai dengan kebutuhan rakyat dalam menentukan pempinan politik daerah, akan menarik minat rakyat daerah untuk berperan serta. Sikap dewasa dalam berdemokrasi merupakan sikap yang mengindikasikan adanya kesadaran dan kemauan politik seseorang untuk mematuhi dan menjunjung tinggi nilai-nilai demokrasi. Di dalamnya, persoalan kepatuhan akan aturan main demokrasi benar-benar dipegang teguh dan semaksimal mungkin dia terapkan di dalam setiap pristiwa atau momentum demokrasi.

Tidak terkecuali ketika dirinya melakoni pemilukada sebagai salah satu wujud demokrasi. Karenanya, seseorang yang memiliki sikap dewasa dalam berdemokrasi akan selalu menghindarkan diri bahkan menolak secara tegas cara-cara yang dinilainya demokratis itu. Kalaupun dirinya berniat membangun pertisipasi politik warga masyarakat untuk seide dan sejalan dengan sikap politiknya, hal itu dilakukan secara santun berdasarkan prinsip demokrasi. Semua berlangsung dalam suasana yang kondusif, dialogis, argumentative, egaliter, dan berorientasi demi kemajuan bersama. Kedewasaan berdemokrasi seseorang juga ditunjukkan dengan kekonsistenannya dalam membudayakan sikap baik sangkanya (husnuzhan) kepada pihak lain yang secara kebetulan tengah berperan sebagai 'lawan politiknya'. Berbaik sangka adalah kunci keberbasilan di tengah upaya dan harapan akan lahirnya suasana perhelatan politik yang membebaskan dari fenomena saling mejatuhkan, memperolok, fitnah, serta ber — black campaig. OIeh karena itu, kehadiran pandangan dan figur lawan politik seharusnya disambut potif. Kehadirannya mesti dinilai membawa potensi kebaikan. Soal mana yang terbaik, bukanlah wilayah kita untuk menjustifikasinya. Tetapi biaranlah publik, melalui pilihan dibilik suaranya, yang menentukannya. Hal lain yang mencolok pada seseorang yang memiliki sikap demokrasi adalah besarnya rasa cinta, rasa persaudaraan (ukhuwah), kerjasama, dan persatuan dalam dirinya. Perasaan ini membuat yang bersangkutan tetap memandang penting kebersamaan dan kekompakan dengan sesama meskipun di antara mereka sempat terfragmentasi ke dalam kelompok-kelompok kekuatan politik dan dukung-mendukung kekuatan politk tertentu.

\section{KESIMPULAN DAN SARAN}

Kratis dalam pembuatan dan pelaksanaannya. Pada akhirnya keseriusan dan ketegasan pemerintah dalam menyikapai kersemerawutan pelakasanaan pemilu Penyederhanaan dan penataan waktu waktu merupakan opsi logis yang harus diambil. Pilkada serentak tahun 2015 yang merupakan rangkaian pilihan utama. Kabupaten Sintang yang merupak salah satu kabupaten/kota yang melaksanakan Pilkada. Perkembangan demokrasi lokal dalam pemilihan kepala daerah sercara langsung merupakan peluang sekaligus tantangan yang perlu pembuktian secara nyata. Bingkai pilkada langsung ini tentunya harus diletakkana dalam asa pemerintahan desentralisasi dalam koridor sistem negara kesatuan. Hubungan state and society dalam pemerintahan daerah di era refromasi ini merupakan tantangan dalam kehidupan pemerintahan modern . Penyelenggaraan pilkada dengan kebijakan publik yang berlandaskan demokrasi yang melibatkan sebanyak mungkin aktor-aktor secara langsung ataupun tidak langsung akan menghasilkan pemilu yang sesuai dengan tujuannya penyerahan kedaulatan secara sukarela. Perangkat kebijakan publik yang mendukung dan jelas, tidak adanya benturan antar kebijakan dan badan penyelenggara merupakan salah satu kunci sukses pimilukada langsung. Setiap produk kebijakan publik yang dihasilkan lembaga politik yang dialakukan secara demokratis pun tidak akan terhindar dari pro dan kontar dalam lingkungan internal dan eksternal kebijakan tersebut. Laswell pernah menyatakan bahwa tidak ada satu kebijakanpun yang dapat memeberiak kepuasan bagi seluruh target kebijaka tersebut. Apalagi kalau produk kebijakan itu mengurangi kadar demokrasi

Akhirnya, semoga kebijakan publik yang sudah diputuskan tentang pemerintahan daerah dan pilkada langsung sebagai amanat dari amandemen UUD 1945 dapat dilaksanakan dan diinterpretasikan dengan baik sehingga tidak mencederai niatnya dalam mengusung demokrasi lokal dalam format desentralisasi betuk devolusi-otonomi daerah. Pilkada langsung di Kabupaten ini diharapkan tidak hanya an old one in a new bottle, tetapi menjadi tonggak perkembangan reformasi politik local. Diharapkan sikap dewasa dalam berdemokrasi merupakan sikap yang mengindikasikan adanya kesadaran dan kemauan politik seseorang untuk mematuhi dan menjunjung tinggi nilai-nilai demokrasi. Di dalamnya, persoalan kepatuhan akan aturan main dalam pemilihan kepala daerah benarbenar dipegang teguh dan semaksimal mungkin dia terapkan di dalam setiap pristiwa atau momentun demokrasi. Tidak terkecuali ketika dirinya melakoni pemilukada sebagai salah satu wujud demokrasi. karenanya, seseorang yang memiliki sikap dewasa dalamberdemokrasi akan selalu menghindarkan diri bahkan menolak secara tegas cara-cara yang dinilainya demokratis itu. Kalaupun dirinya berniat membangun pertisipasi politik warga masyarakat 
untuk seide dan sejalan dengan sikap politiknya, hal itu dilakukan secara santun berdasarkan prinsip demokrasi. Semua berlangsung dalam suasana yang kondusif, dialogis, argumentative, egaliter, dan berorientasi demi kemajuan bersama.

\section{DAFTAR PUSTAKA}

Amirudin dan A. Zaini Bisri, 2006. Pilkada Langsung Problem dan Prospek, Pustaka Pelajar, Yogyakarta

Atip Tartiana, 2010. Tahun Pemilukada 2010, artikel dalam Pikiran Rakyat, 5 Januari 2010

Budiardjo, Miriam, 1994, Demokrasi di Indonesia: Demokrasi Parlementer dan Demokrasi Pancasila, PT Gramedia Pustaka Utama, Jakarta

Faturohman, Deden dan Wawan Sobari, 2002, Pengantar Ilmu Politik, UMM Press, Malang.

Hendri Zainudin, 2907. Pemilukada dan Kedewasaan Berdemokrasi, Berita Pagi, Rabu 12 Desember 2007

Irvan Mawardi, 2008. Pilkada dan Partisipasi Politik, artikel dalam www. jppr.org
Lay, Cornelis,2003, “Otnomi Daerah dan KeIndonesiaan” dalam Abdul Gaffar Karim (ed.), Kompleksitas Persoalan Otonomi di Indonesia, Pustaka Pelajar, Yogyakarta.

Pratikno, 2003, Pilihan yang Tidak Pernah Final, Dalam Abdul Gaffar Karim (Ed.), Desentralisasi, , Kompleksitas Persoalan Otnomi Daerah di Indonesia, Pustaka Pelajar, Yogyakarta.

Riyadmaji, Dodi, 2003, Mengkritisi Pemikiran Pemilihan Kepala Daerah Secara Langsung, dalam Abdul Gaffar Karim (ed.), Kompleksitas Persoalan Otonomi di Indonesia, Pustaka Pelajar, Yogyakarta.

Sinaga, Kastorius, 2003, Pemilihan Kepala Daerah Langsung Kota dan Kabupaten: Beberapa catatan Awal, dalam Abdul Gaffar Karim (ed.), Kompleksitas Persoalan Otonomi di Indonesia, Pustaka Pelajar, Yogyakarta

Sjafii, Inu Kencana, 1994, Pengantar Ilmu Pemerintahan, CV. Mandar Madju, Bandung.

Tim Pustaka Kendi, 2004, Desentralisasi dalam Prakrtek, tejemahan dari Henry 